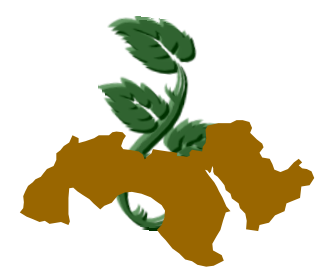

Arab Univ.

J. Agric. Sci., Ain Shams Univ., Cairo, 22(2), 361 - 369, 2014

\title{
SALT TOLERANCE INDEX OF TWENTY TWO SUGAR BEET (Beta vulgaris L.) VARIETIES AT EARLY STAGES OF GROWTH
}

\author{
Abd El-Hady' ${ }^{1}$, M.A.; T.Y. Rizk ${ }^{1}$; M.E. El-Bially ${ }^{1}$ and M.A. Farag ${ }^{2}$ \\ 1- Agronomy Dept., Faculty of Agric., Ain Shams Univ., Shoubra El-Kheima, Cairo, \\ Egypt \\ 2- Sugar Crops Res. Inst., Agric. Res. Center, Giza, Egypt
}

Keywords: Sugar beet; Salt tolerance index; Salinity stress and germination percentage

\section{ABSTRACT}

A laboratory experiment was carried out to study the early growth response of 22 sugar beet (Beta vulgaris, L.) varieties to four salt concentrations of seawater i.e. 2000, 4000, 8000 and 16000 ppm. Germination and seedling growth traits (germination percentage (\%), germination rate, seedling length $(\mathrm{cm})$, seedling fresh weight $(\mathrm{mg})$ and seedling vigor) were determined at the end of the experiment after 30 days from planting. The results showed that increasing the salinity level decreased the germination \%, germination rate, seedling length, seedling fresh weight and seedling vigor of all sugar beet varieties under investigation to different extents. The results also clearly revealed that the response of the investigated varieties to salt concentrations was not the same, some varieties approved to be highly salt tolerant i.e. Soultan, Kawmira and Desprez; others were very sensitivity tolerant i.e. Helsiniki and LP16. However most of the investigated varieties were moderately salt tolerant. Results revealed clearly that the interaction effect between sugar beet varieties and salt concentrations was significant. This significant effect means that the tested varieties do not behave the same under the different levels of salinity stress.

\section{INTRODUCTION}

The problem of salinity is of great concern for agricultural countries, like Egypt where about 2 million Faddan (25\% from the cultivated area) are salt affected land. Sugar beet is among the most salt tolerant crops, but is to be less tolerant during germination and emergence (Kaffka and Kurt, 2004). The detrimental effects of increasing salinity level and the interaction between salinity levels and sugar beet varieties on germination and seedling growth are early reported by many investigators among them, Kaffka and Hembree (2004) they reported that sugar beet is among the most salt tolerant crops, but is to be less tolerant during germination and emergence. They also found that seedling dry weight and the rate of emergence declined at EC levels greater than 6dSm'. Jamil et al (2007) reported that with increasing salt concentration from 0.0 up to $150 \mathrm{mM} \mathrm{Nacl}$ decreased significantly dry root and shoot weight, fresh leaf weight and leaf area, whereas there were no changes in dry leaf weight and leaf water contents. However, leaf chlorophyll content was increased significantly with increasing salt concentration in sugar beet seedlings. Dadkhah (2011) studied the effect of different levels of salinity $(0.0$, $50,150,250$ and $350 \mathrm{mM}$ ) on growth of two sugar beet varieties namely Madison and 7233- $\mathrm{P}_{29}$. Plants were harvested after 8 weeks from sowing. Total dry matter of plants at the highest salinity level $(350 \mathrm{mM})$ was decreased by $50.6 \%$ (mean of both varieties) compared to control. Salinity stress reduced shoot and root dry weights for both varieties, but the reduction in root dry weight was greater than shoot dry weight.

The current work aims to test the salt-tolerance of 22 sugar beet varieties as well as the different responses to seawater concentrations at germination stage i.e. germination percentage, germination rate and seedling vigor.

MATERIALS AND METHODS 
A laboratory experiment was carried out at the Fac. of Agric., Ain Shams Univ., at Shoubra ElKheima, Kalubia Governorate during 2008. The experiment aimed to test the salt tolerance of twenty two sugar beet varieties; namely Clorvis, Soultan, Motabinco, Ras poly, Kawmira, Toro, Helsiniki, FD 9902, Egypt 06nn1, Dema poly, LP 16, FD 9901, Tenor, LP 13, Baraca, MK 2134, Samba, Henol, Egypt o6nn2, MK 2135, Maghribel and Desprez. It is worth to mention that seeds of 20 varieties of the previous tested 22 varieties were polygerm, while two varieties namely (Helsiniki and LP16) were monogerm. The used seeds were planted in sand culture in standard plastic germination trays (each tray contains 50 seeds) and irrigated with equal amounts of the following three concentrations of diluted seawater i.e. 2000, 4000, 8000 and 16000 ppm for each variety. Seawater used in this work was obtained from Marsa Matruh beach region. The chemical composition of the used seawater are shown in Table (1).

Table 1. The chemical content of the used seawater

\begin{tabular}{|c|c|c|c|c|c|c|c|}
\hline \multirow{2}{*}{ pH } & \multirow{2}{*}{$\begin{array}{c}\mathrm{EC} \\
\mathrm{dS} / \mathrm{m}\end{array}$} & \multicolumn{4}{|c|}{ Cation (me/L) } & \multicolumn{2}{|c|}{$\begin{array}{l}\text { Anions } \\
\text { (me/L) }\end{array}$} \\
\hline & & $\mathrm{Ca}^{++}$ & $\mathrm{Mg}^{++}$ & $\mathrm{Na}^{+}$ & $\mathrm{K}^{+}$ & $\mathrm{HCO}_{3}=$ & $\mathrm{Cl}^{-}$ \\
\hline 7.96 & 54.8 & 21.25 & 116.7 & 434.7 & 16 & 2.59 & 610 \\
\hline
\end{tabular}

The germination trays were arranged in a completely randomized design with four replicates of each treatment. Germination and seedling growth traits (germination percentage (\%) after 15 days from sowing, germination rate, seedling length nearest $(\mathrm{cm})$, seedling fresh weight nearest $(\mathrm{mg})$ and seedling vigor ${ }^{1}$ ) were determined at the end of the experiment after 30 days from planting.

${ }^{1}$ seedling vigor was calculated using the following equation: Seedling vigor $=$ Germination percentage $(\%) X$ Seedling length $(\mathrm{cm})$

\section{Statistical analysis}

The obtained data were subjected to the proper statistical analysis of variance by using complete randomized design according to SAS (1995). Duncan's multiple range was used to differentiate between means.

\section{RESULTS AND DISCUSSION}

\section{Effect on Germination percentage}

Data presented in Table (2) demonstrate the effect of three salt concentrations of seawater i.e. 2000,4000 and 8000 ppm on the germination \% of the twenty two sugar beet varieties. Results revealed that increasing the salinity level decreased the germination\% of all sugar beet varieties under investigation to different extents. The mean values of the germination percentages over all varieties were significantly different and amounted 72, 69 and $59 \%$ at the salinity levels of 2000, 4000 and 8000 ppm, respectively. The detrimental effects of increasing salinity level on germination and growth of crop plants are early reported by many investigators. Recently Jafarzadeh and Allasgharzad (2007) studied the effect of salinity on seed germination and root length of four sugar beet cultivars. They found that germination and root length were significantly affected by salinity levels, cultivars and salt composition. They added that the adverse effect of salinity of the irrigation water up to $8 \mathrm{ds} / \mathrm{m}$ on seed germination and seedling root length was higher for $\mathrm{Nacl}$ alone than for the salt mixture of $\left(\mathrm{MgSO}_{4}+\mathrm{Nacl}+\mathrm{Na}_{2} \mathrm{So}_{4}+\mathrm{Cacl}_{2}\right)$, which refers to lower salt stress in field conditions with natural salt composition. Rizk et al (2002) attributed the depression in germination \% either due to the increase in the osmotic concentration through decreasing the rate and the total amounts of water absorbed, therefore seeds cannot absorbed all water required for germination, or due to the specific toxic effects of salts on germination and growth of plants due to the adverse effect of the salts on the enzymatic processes.

The present results also revealed that, the response of the investigated sugar beet varieties to salt concentrations was not the same, some varieties approved to be salt tolerant, i.e. Soultan, Kawemira and Desprez and other varieties were very salt sensitive, i.e. Helsiniki and LP16 and the majority of the tested varieties were in between. Meanwhile, it is worth to mention here that 20 varieties out of the 22 tested varieties were completely failed to germinate at the highest level of salinity (16000 ppm). The only two varieties i.e. Soultan and Kawmira showed germination \% of 20 and $17 \%$ respectively at the that level of salinity (16000). Due to the failed of most of the tested sugar beet varieties (20 out of the 22 varieties) to germinate at the salt level of 16000 ppm, the mean 
values of the tested varieties were recalculated after excluding the obtained results of that level of salinity (16000 ppm).The germination \% of the salt tolerant varieties Soultan and Kawemira were more than $90 \%$. Moreover these two varieties resist the salinity level up to $16000 \mathrm{ppm}$ and their germination $\%$ at that level were 20 and $17 \%$, respectively. On the other hand the germination \% of the two sensitive varieties were less than $30 \%$ at the lowest level of salinity (2000 ppm). Increasing the salinity level from 2000 to 4000 or 8000 ppm did not significantly reduce the germination \% of the three salt tolerant varieties (Soultan, Kawemira and Desprez), but this was not the case with the two sensitive varieties, their germination percentage were decreased sharply by increasing the salt concentration from 2000 to 4000 ppm. The germination \% of most of the tested varieties (17 varieties) were not significantly affected by increasing the salinity level from 2000 to 4000 ppm. Results also showed that increasing the salt concentration from 4000 to $8000 \mathrm{ppm}$ did not affect significantly the germination \% of 10 varieties (Soultan, Kawemira, Toro, Helsiniki, Dema poly, Lp 16, Tenor, Baraka, Samba, Henol and Desprez) as shown in Table (4). The germination percentage of $90 \%$ or more were achieved with seven varieties (Clorvis, Soultan, Kawemira, Lp 13, MK 2134, Maghribel and Desprez) at the level of 2000 ppm $(3.13 \mathrm{ds} / \mathrm{m}$ ); five varieties (Soultan, Kawemira, Lp 13, MK 2134 and Desprez) at the level of 4000 ppm $(6.26 \mathrm{ds} / \mathrm{m})$ and two varieties (Soultan and Kawemira) at the level of $8000 \mathrm{ppm}(10 \mathrm{ds} / \mathrm{m})$. Results also showed that among the 22 varieties under investigation only 10 varieties (Clorvis, Soultan, Kawemira, Lp 13, MK 2134, Henol, Egypt 06nn1, MK 2135, Maghribel and Desprez) recorded germination of $80 \%$ or more and six varieties (Motabinco, Helsiniki, FD 9902, Dema poly, Lp 16 and FD 9901) recorded germination \% less than $60 \%$.

Moreover at $8000 \mathrm{ppm}$ level of salinity only four varieties (Soultan, Kawemira, MK 2134 and Desprez) showed germination of $80 \%$ or more and 10 varieties (Motabinco, Ras poly, Helsiniki, FD 9902, Egypt 06nn2, Dema poly, Lp 16, FD 9901, Lp 13 and Baraka) recorded germination percentages less than 60 . These results revealed clearly that the interaction effect between sugar beet varieties and salt concentrations on germination percentage was significant.
Table 2. Germination percentages of sugar beet varieties as affected by salinity levels (after 15 days from sowing)

\begin{tabular}{|c|c|c|c|c|}
\hline \multirow{2}{*}{ Varieties } & \multicolumn{3}{|c|}{ Salinity levels (ppm) } & \multirow{2}{*}{ Means } \\
\hline & 2000 & 4000 & 8000 & \\
\hline 1- Clorvis & $90 a b c$ & $88 \mathrm{bc}$ & 74 cde & $84 \mathrm{D}$ \\
\hline 2- Soultan & $96 \mathrm{a}$ & $96 \mathrm{a}$ & $90 \mathrm{abc}$ & $94 \mathrm{~A}$ \\
\hline 3- Motabinco & 58 ef & 62 ef & $54 \mathrm{f}$ & $58 \mathrm{HI}$ \\
\hline 4- Ras poly & $78 \mathrm{~cd}$ & $76 \mathrm{~cd}$ & $50 \mathrm{f}$ & $68 \mathrm{G}$ \\
\hline 5- Kawemira & $92 a b$ & $90 \mathrm{abc}$ & $90 \mathrm{abc}$ & $91 A B$ \\
\hline 6- Toro & 62 ef & $68 \mathrm{de}$ & $64 \mathrm{e}$ & $65 \mathrm{G}$ \\
\hline 7- Helsiniki & $24 i$ & $00 \mathrm{k}$ & $00 \mathrm{k}$ & $8 \mathrm{M}$ \\
\hline 8- FD 9902 & 58 ef & 56 ef & $44 \mathrm{~g}$ & 531 \\
\hline 9- Egypt 06nn2 & 64 e & 62 ef & $54 \mathrm{f}$ & $60 \mathrm{H}$ \\
\hline 10- Dema poly & 58 ef & 58 ef & $50 \mathrm{f}$ & $55 I$ \\
\hline 11- Lp 16 & $28 \mathrm{i}$ & $12 \mathrm{j}$ & $10 \mathrm{j}$ & $17 \mathrm{~L}$ \\
\hline 12- FD 9901 & $54 f$ & $42 \mathrm{~g}$ & $36 \mathrm{~h}$ & $44 \mathrm{~K}$ \\
\hline 13- Tenor & 70 de & 62 ef & 62 ef & $65 \mathrm{G}$ \\
\hline 14- Lp 13 & $90 a b c$ & $94 \mathrm{a}$ & 58 ef & $81 \mathrm{DE}$ \\
\hline 15- Baraka & 62 ef & $54 \mathrm{f}$ & $52 \mathrm{f}$ & $56 \mathrm{HI}$ \\
\hline 16- MK 2134 & $94 \mathrm{a}$ & $92 a b$ & $80 \mathrm{c}$ & $89 \mathrm{BC}$ \\
\hline 17- Samba & $70 \mathrm{de}$ & 74 cde & $68 \mathrm{de}$ & $71 \mathrm{FG}$ \\
\hline 18- Henol & 82 bc & $80 \mathrm{c}$ & $78 \mathrm{~cd}$ & 8DEF \\
\hline 19-Egypt 06nn1 & $84 \mathrm{bc}$ & 82 bc & $66 \mathrm{e}$ & $77 \mathrm{EF}$ \\
\hline 20- MK 2135 & $82 \mathrm{bc}$ & 82 bc & 62 ef & $75 \mathrm{EF}$ \\
\hline 21- Maghribel & $90 a b c$ & $88 \mathrm{bc}$ & $76 \mathrm{~cd}$ & $85 C D$ \\
\hline 22- Desprez & $94 \mathrm{a}$ & $94 \mathrm{a}$ & $86 \mathrm{bc}$ & $91 A B$ \\
\hline Means & $72 \mathrm{~A}$ & $69 \mathrm{~A}$ & $59 \mathrm{~B}$ & \\
\hline
\end{tabular}

This significant effect means that germination $\%$ of the tested varieties do not behave the same under the different levels of salinity. Similar findings were reported by several authors on different crops, i.e Rizk, et al (2002) on alfalfa and Egyptian clover, on sugar beet, (Heur and Plaut 1989), Ghoulam et al (2002); Kaffka \& Hembree (2004); Jamil et al (2007) and Jafarzadeh \& Allasgharzad (2007). Kaffka and Hembree (2004) studied the effect of soil and irrigation water salinity on sugar beet (Beta vulgaris L.) emergence and seedling growth. They reported that rates of emergence and seedling dry weight were reduced, but not final stand counts at EC levels greater than $6.0 \mathrm{ds} / \mathrm{m}$ in gypsum dominated soil. Recently Jafarzadeh and Allasgharzad (2007) tested the effect of water salinity levels and salt composition on germination percentage of four sugar beet cultivars (PP22, IC2, PP36, and 7233). The experiments consisted irrigation water with two salt compositions $\left(\mathrm{NaCl}\right.$ alone and mixture of $\mathrm{MgSO}_{4}+\mathrm{NaCl}+$ $\mathrm{Na}_{2} \mathrm{SO}_{4}+\mathrm{CaCl}_{2}$ ). Thirteen salinity levels with electrical conductivity (EC) of the irrigation water ranging from 0 to $30 \mathrm{dS} / \mathrm{m}$ were applied. The results showed that germination percentage was 
significantly affected by salt composition, cultivars and salinity levels. Seed germination was significantly affected by the irrigation water with EC up to $8 \mathrm{ds} / \mathrm{m}$ and $4 \mathrm{ds} / \mathrm{m}$, except for cultivar PP22, the adverse effect of salinity of the irrigation water on seed germination was higher for $\mathrm{NaCl}$ alone than for the salt mixture, which refers to lower salt stress in field conditions with natural salt composition.

\section{Effect on Germination rate}

The obtained results revealed generally that there were insignificant decreases in the germination rate as affected by the different salinity levels (Table 3 ). This finding revealed that increasing salinity levels from 2000 ppm up to 8000 ppm had insignificant effects on germination rate of all studied varieties. Results also showed that the varieties Kawmira, Tenor, Baraka, Samba, Mk2135, Meghribel, Egypt 06nn2 and Toro recorded the highest mean values in germination rate. On the other hand, the lowest mean values were recorded by the two salt sensitive varieties (Helsiniki and LP16). Variations in germination rate between the studied 22 sugar beet varieties at salinity levels of 2000 and 4000 and 8000 ppm were not great enough to reach the significant level.

Table 3. Germination rate of sugar beet varieties as affected by salinity levels

\begin{tabular}{|c|c|c|c|c|}
\hline \multirow[t]{2}{*}{ Varieties } & \multicolumn{3}{|c|}{ Salinity levels (ppm) } & \multirow[t]{2}{*}{ Means } \\
\hline & 2000 & 4000 & 8000 & \\
\hline is & $0.75 b$ & $0.77 \mathrm{ab}$ & $0.725 \mathrm{bc}$ & $0.75 \mathrm{AB}$ \\
\hline 2- Soultan & $0.78 \mathrm{ab}$ & $0.75 \mathrm{bc}$ & $0.68 \mathrm{~cd}$ & $0.74 \mathrm{~B}$ \\
\hline 3- Motabinco & $0.77 \mathrm{ab}$ & $0.7 \mathrm{abc}$ & $0.73 \mathrm{bc}$ & $0.75 A B$ \\
\hline 4- Ras poly & $0.77 \mathrm{ab}$ & $0.79 \mathrm{a}$ & $0.70 \mathrm{c}$ & $0.75 A B$ \\
\hline awemira & $0.78 \mathrm{ab}$ & $0.77 \mathrm{ab}$ & $0.76 \mathrm{abc}$ & $0.77 \mathrm{~A}$ \\
\hline 6- $T$ & $0.76 a b c$ & $0.75 \mathrm{bc}$ & $0.77 \mathrm{ab}$ & $0.76 \mathrm{~A}$ \\
\hline iniki & $0.75 \mathrm{bc}$ & $0.00 \mathrm{~g}$ & $0.00 \mathrm{~g}$ & $5 \mathrm{E}$ \\
\hline 8- FD 9902 & $0.74 \mathrm{bc}$ & $0.78 a b$ & $0.72 \mathrm{bc}$ & $0.75 A B$ \\
\hline 06nn2 & $0.76 a b c$ & $0.77 \mathrm{ab}$ & $0.74 \mathrm{bc}$ & $6 \mathrm{~A}$ \\
\hline ema poly & $0.75 b c$ & 4 bc & $0.76 a b c$ & $5 A B$ \\
\hline 11- Lp 16 & $0.74 b c$ & $0.60 \mathrm{e}$ & $0.56 f$ & $0.63 \mathrm{D}$ \\
\hline 9901 & $0.77 \mathrm{ab}$ & $0.74 \mathrm{bc}$ & $0.73 \mathrm{bc}$ & $0.75 A B$ \\
\hline & $0.78 \mathrm{ab}$ & $0.77 \mathrm{ab}$ & $0.76 \mathrm{abc}$ & $7 \mathrm{~A}$ \\
\hline LP 13 & $0.76 a b c$ & $0.75 \mathrm{bc}$ & $0.74 \mathrm{bc}$ & $0.75 A B$ \\
\hline raka & $0.77 \mathrm{ab}$ & $0.77 \mathrm{ab}$ & $0.74 \mathrm{bc}$ & $0.76 \mathrm{~A}$ \\
\hline 2134 & $0.66 \mathrm{~d}$ & $0.73 \mathrm{bc}$ & $0.70 \mathrm{c}$ & $0.70 \mathrm{C}$ \\
\hline $17-\mathrm{S}$ & $0.78 \mathrm{ab}$ & $0.76 \mathrm{abc}$ & $0.74 \mathrm{bc}$ & $0.76 \mathrm{~A}$ \\
\hline 18- Henol & $0.77 \mathrm{ab}$ & $0.76 a b c$ & $0.73 \mathrm{bc}$ & $0.75 A B$ \\
\hline 19-Egypt 06nn1 & $0.74 \mathrm{bc}$ & $0.75 \mathrm{bc}$ & $0.73 \mathrm{bc}$ & $0.74 \mathrm{~B}$ \\
\hline 20-MK 2135 & $0.77 \mathrm{ab}$ & $0.75 \mathrm{bc}$ & $0.75 \mathrm{bc}$ & $0.76 \mathrm{~A}$ \\
\hline 21- Maghribel & $0.78 \mathrm{ab}$ & $0.76 a b c$ & $0.74 \mathrm{bc}$ & $0.76 \mathrm{~A}$ \\
\hline 22- Desprez & $0.78 a b$ & $0.72 \mathrm{bc}$ & $0.74 \mathrm{bc}$ & $0.75 A B$ \\
\hline Means & $0.76 \mathrm{~A}$ & $0.75 \mathrm{~A}$ & $0.73 \mathrm{~A}$ & \\
\hline
\end{tabular}

Therefore many investigators studied the effect of salinity stress on germination rate, among them Kaffka and Kurt (2004) who studied the effect of soil and irrigation water salinity on sugar beet (Beta vulgaris L.) emergence. They found that the rate of emergence was declined at EC. levels greater than $6 \mathrm{dSm}-\mathrm{I}$ (3840 ppm).

\section{Effect on seedling length}

The data presented in (Table 4) demonstrate the effect of salinity levels, sugar beet varieties and their interaction on seedling length $(\mathrm{cm})$ after 30 days from sowing. The results indicated that increasing salinity levels from $2000 \mathrm{ppm}$ to 8000 ppm decreased seedling length for all studied varieties to different extents. The highest values of seedling lenght were recorded at $2000 \mathrm{ppm}$ for Soultan $(7.2 \mathrm{~cm})$, Clorvis $(7.1 \mathrm{~cm})$ and Desprez $(7$ $\mathrm{cm})$, and the lowest values were obtained with Helsiniki $(4.1 \mathrm{~cm})$ and Lp $16(4.9 \mathrm{~cm})$.

There was positive correlation between seedling length (Table 4) and germination percentages (Table 2). The varieties that gave higher values in germination percentage gave higher values in seedling length and vice versa. Increasing salinity levels up to 8000 ppm did not significantly affect several varieties such as; Soultan, Clorvis, Maghribal and others but decreased significantly the seedling length of other varieties, such as Kawmera, Egypt 06nn2, Lp 16, Tenor and others. Similar results were early reported by many investigators. Jafarzadeh and Allasgharzad (2007) tested the effect of water salinity levels and salt composition on seedling root length of four sugar beet cultivars (PP22, IC2, PP36 and 7233). Thirteen salinity levels with electrical conductivity (EC) of the irrigation water ranging from 0 to 30 $\mathrm{dS} / \mathrm{m}$ were applied. Seedling root length was determined at 13 days. Their results showed that seedling root length was significantly affected by salt composition, cultivars and salinity levels. Seedling root length were significantly affected by the irrigation water with EC up to $4 \mathrm{dS} / \mathrm{m}$ and $8 \mathrm{dS} / \mathrm{m}$, except for cultivar PP22 where the adverse effect of salinity of the irrigation water on seedling root length was higher for $\mathrm{NaCl}$ alone than for the salt mixture, which refers to lower salt stress in field conditions with natural salt composition. 
Table 4. Seedling length $(\mathrm{cm})$ of sugar beet varieties as affected by salinivy levels (after 30 days from sowing)

\begin{tabular}{|c|c|c|c|c|}
\hline \multirow[t]{2}{*}{ Varieties } & \multicolumn{3}{|c|}{ Salinity levels (ppm) } & \multirow[b]{2}{*}{ Means } \\
\hline & 2000 & 4000 & 8000 & \\
\hline 1- Clorvis & $7.1 \mathrm{a}$ & $6.5 a b$ & $6.6 \mathrm{ab}$ & $6.7 \mathrm{AB}$ \\
\hline 2- Soultan & $7.2 \mathrm{a}$ & $6.9 \mathrm{ab}$ & $6.7 \mathrm{ab}$ & $6.9 \mathrm{~A}$ \\
\hline 3- Motabinco & $6.5 a b$ & $5.9 \mathrm{bc}$ & $5.4 \mathrm{bc}$ & $5.9 \mathrm{BC}$ \\
\hline 4- Ras poly & 6.abc & $6.3 a b$ & $4.9 \mathrm{bc}$ & $5.8 \mathrm{C}$ \\
\hline 5- Kawemira & $6.7 \mathrm{ab}$ & $6.2 \mathrm{abc}$ & $5.3 \mathrm{bc}$ & $6.1 \mathrm{BC}$ \\
\hline 6- Toro & $6.1 \mathrm{bc}$ & $5.3 \mathrm{bc}$ & $5.8 \mathrm{bc}$ & $5.7 \mathrm{C}$ \\
\hline 7- Helsiniki & $4.1 \mathrm{c}$ & $0.0 \mathrm{f}$ & $0.0 \mathrm{f}$ & $1.4 \mathrm{E}$ \\
\hline 8- FD 9902 & $6.5 a b$ & $6.4 a b$ & $5.5 \mathrm{bc}$ & $6.1 \mathrm{BC}$ \\
\hline 9-Egypt 06nn2 & $6.4 \mathrm{ab}$ & $6.2 \mathrm{abc}$ & $5.2 \mathrm{bc}$ & $5.9 \mathrm{BC}$ \\
\hline 10- Dema poly & $6.4 a b$ & $5.9 \mathrm{bc}$ & $5.4 \mathrm{bc}$ & $5.9 \mathrm{BC}$ \\
\hline 11- Lp 16 & $4.9 \mathrm{bc}$ & $2.9 \mathrm{~d}$ & $1.7 \mathrm{e}$ & $3.2 \mathrm{D}$ \\
\hline 12-FD 9901 & $5.8 \mathrm{bc}$ & $6.0 \mathrm{bc}$ & $5.8 \mathrm{bc}$ & $5.9 \mathrm{BC}$ \\
\hline 13- Tenor & $6.3 a b$ & $5.4 \mathrm{bc}$ & $5.2 \mathrm{bc}$ & $5.6 \mathrm{C}$ \\
\hline 14- Lp 13 & $6.5 a b$ & $6.6 a b$ & $4.3 \mathrm{c}$ & $5.8 \mathrm{C}$ \\
\hline 15- Baraka & $6.4 a b$ & $6.1 \mathrm{bc}$ & $5.4 \mathrm{bc}$ & $6.0 \mathrm{BC}$ \\
\hline 16-MK 2134 & $6.8 a b$ & $6.2 \mathrm{abc}$ & $5.9 \mathrm{bc}$ & $6.3 \mathrm{~B}$ \\
\hline 17- Samba & $6.3 \mathrm{ab}$ & $6.3 a b$ & $5.2 \mathrm{bc}$ & $5.9 \mathrm{BC}$ \\
\hline 18- Henol & $6.4 a b$ & $6.1 \mathrm{bc}$ & $6.2 a b c$ & $6.2 \mathrm{BC}$ \\
\hline 19-Egypt 06nn1 & 6.2abc & $5.8 \mathrm{bc}$ & $5.3 \mathrm{bc}$ & $5.8 \mathrm{C}$ \\
\hline 20- MK 2135 & $6.1 \mathrm{bc}$ & $6.1 \mathrm{bc}$ & $5.2 \mathrm{bc}$ & $5.8 \mathrm{C}$ \\
\hline 21-Maghribel & $6.7 a b$ & $6.8 \mathrm{ab}$ & $6.8 \mathrm{ab}$ & $6.8 \mathrm{~A}$ \\
\hline 22- Desprez & $7.0 \mathrm{a}$ & $6.7 \mathrm{ab}$ & $5.4 \mathrm{bc}$ & $6.4 \mathrm{AB}$ \\
\hline Means & $6.3 \mathrm{~A}$ & $5.8 \mathrm{~A}$ & $5.1 \mathrm{~B}$ & \\
\hline
\end{tabular}

\section{Effect on seedling fresh weight}

Data in (Table 5) showed the effect of salinity levels, sugar beet varieties and their interaction on seedling fresh weight $(\mathrm{mg})$. Results showed that increasing salinity levels from 2000 ppm to 8000 ppm caused significant decreases in seedling fresh weight for almost all studied varieties with few exceptions i.e, Soultan, Kawemira, MK2134, Clorvis and Maghribel. Moreover two varieties namely Soultan and Clorvis showed insignificant increases in seedling fresh weight by increasing the salinity level up to $8000 \mathrm{ppm}$. Meanwhile, it is worth to mention that the seedling fresh weight of the two highly salt tolerant varieties (Soultan and Kawemira) were sharply decreased at the salinity levels of $16000 \mathrm{ppm}$. The highest and the lowest values were generaly recorded by the salt treatments of 2000 ppm and 8000 ppm respectively. Results also showed that the varieties Soultan and MK2134 recorded the highest mean values of seedling fresh weight (50.5 and $50.2 \mathrm{mg}$ ), respectively followed by Kawmira (49.9 mg) and Maghribil $(49.8 \mathrm{mg}$ ) while the variety Helsiniki recorded the lowest mean value $(10 \mathrm{mg}$. In respect to the inter- action effect between salinity levels and sugar beet varieties on seedling fresh weight results showed that the response of the investigated sugar beet varieties differed greatly according to salinity levels. This significant effect of the above interaction means that the varieties did not respond similarly to the salinity levels. The seedling fresh weight of some varieties (Soultan, Clorvis, Kawemira, MK2134 and Maghribel) was not significantly affected by salt concentration up to $8000 \mathrm{ppm}$. This last finding was not true with other varieties (Toro, FD9901, Baraka and others) which showed significant decreases in seedling fresh weight. Therefore several investigators studied the effect of salinity levels on seedling fresh weight.

Table 5. Seedling fresh weight $(\mathrm{mg})$ of sugar beet varieties as affected by salinity levels (after 30 days from sowing

\begin{tabular}{|c|c|c|c|c|}
\hline \multirow[t]{2}{*}{ Varieties } & \multicolumn{3}{|c|}{ Salinity levels (ppm) } & \multirow[b]{2}{*}{ Means } \\
\hline & 2000 & 4000 & 8000 & \\
\hline 1- Clorvis & $44.4 \mathrm{bc}$ & $46.2 \mathrm{bc}$ & $49.2 \mathrm{ab}$ & 46.6BC \\
\hline 2- Soultan & $49.5 a b$ & $51.0 \mathrm{a}$ & $50.9 \mathrm{a}$ & $50.5 \mathrm{~A}$ \\
\hline 3- Motabinco & $40.3 \mathrm{cde}$ & $41.4 \mathrm{~cd}$ & $39.3 \mathrm{de}$ & $40.3 C D$ \\
\hline 4- Ras poly & $44.0 \mathrm{~cd}$ & $42.5 \mathrm{~cd}$ & 33.3 ef & $39.9 \mathrm{CD}$ \\
\hline 5- Kawemira & $50.3 a b$ & $50.5 \mathrm{ab}$ & $48.8 \mathrm{ab}$ & 49.9AB \\
\hline 6- Toro & $41.6 \mathrm{~cd}$ & $38.7 \mathrm{de}$ & 36.6 ef & $38.9 \mathrm{D}$ \\
\hline 7- Helsiniki & $30.1 \mathrm{f}$ & $00.0 \mathrm{i}$ & $00.0 \mathrm{i}$ & $10.0 \mathrm{~F}$ \\
\hline 8- FD 9902 & 38.6de & 36.4 ef & $34.0 \mathrm{f}$ & $36.3 \mathrm{D}$ \\
\hline 9-Egypt 06 nn2 & $44.6 \mathrm{bc}$ & 36.5 ef & 36.0 ef & $39.0 \mathrm{D}$ \\
\hline 10- Dema poly & $46.2 \mathrm{bc}$ & $38.8 \mathrm{de}$ & 36.6 ef & 40.5CD \\
\hline 11- Lp 16 & $31.8 \mathrm{ef}$ & $16.5 \mathrm{~g}$ & $7.23 \mathrm{~h}$ & $18.5 \mathrm{E}$ \\
\hline 12- FD 9901 & $42.1 \mathrm{~cd}$ & 37.7def & $29.0 \mathrm{f}$ & $36.3 \mathrm{D}$ \\
\hline 13- Tenor & $47.6 \mathrm{bc}$ & $40.5 \mathrm{cde}$ & 39.4 de & 42.5CD \\
\hline 14- LP 13 & $48.8 a b$ & 48.abc & $39.0 \mathrm{de}$ & 45.3BC \\
\hline 15- Baraka & $46.7 \mathrm{bc}$ & 39.2 de & 36.6 ef & $40.8 \mathrm{CD}$ \\
\hline 16- MK 2134 & $50.3 \mathrm{ab}$ & $50.4 \mathrm{ab}$ & $50.0 \mathrm{ab}$ & $50.2 \mathrm{~A}$ \\
\hline 17- Samba & $50.1 \mathrm{ab}$ & $49.2 \mathrm{ab}$ & $45.3 \mathrm{bc}$ & 48.2 AB \\
\hline 18- Henol & $47.0 \mathrm{bc}$ & $43.3 \mathrm{~cd}$ & $42.4 \mathrm{~cd}$ & 44.2 BC \\
\hline 19-Egypt 06nn1 & $37.8 \mathrm{de}$ & 40.1cde & 39.3 de & $39.1 \mathrm{D}$ \\
\hline 20-MK 2135 & $44.1 \mathrm{bcd}$ & $43.2 \mathrm{~cd}$ & 40.4 cde & 42.6BCD \\
\hline 21-Maghribel & $50.3 \mathrm{ab}$ & $50.5 \mathrm{ab}$ & $48.5 \mathrm{ab}$ & $49.8 \mathrm{AB}$ \\
\hline 22-Desprez & $50.2 \mathrm{ab}$ & $50.2 \mathrm{ab}$ & $41.2 \mathrm{cde}$ & 47.2ABC \\
\hline Means & $44.4 \mathrm{~A}$ & $40.8 \mathrm{~B}$ & 37.4 B & \\
\hline
\end{tabular}

Heur and plaut (1989) exposed two sugar beet cultivars (Monriac and Kawemegapoly) to 180 $\mathrm{mol} / \mathrm{m}^{3} \mathrm{Nacl}$. They found that exposed Monriac plants to the salinity level shown enhanced dry and fresh weights production of plants while, growth of Kawemegapoly plants exposed to the same level of salinity was reduced by $17 \%$. Ghoulam et al 
(2002) studied the effect of salinity on growth of five sugar beet (Beta vulgaris, L) varieties (Zwwanpoly, Kawemegapoly, Top, Desprezpoly and Nejma). Plants were submitted to four salinity treatments (0.0 (control), 50, 100, $200 \mathrm{mM} \mathrm{NaCl}$ ) for 30 days in sand culture. The highest $\mathrm{NaCl}$ concentration caused a great reduction in growth parameters such as fresh and dry weights of leaves and roots. Varietal differences were evident at the highest $\mathrm{NaCl}$ concentration for almost all of the tested varieties. Jamil et al (2007) investigated the effect of salinity on seedling growth of sugar beet (Beta vulgaris, L) grown in sand culture at salinities of (0.0 (control), 50, 100, $150 \mathrm{mM} \mathrm{NaCl}$ ). They found that with increasing salt concentration, dry weight of root and shoot, fresh leaf weight were decreased significantly whereas, there were no changes in dry leaf weight. Dadkhah (2011) carried out a pots experiment to investigate the effect of different levels of salinity $(0.0,50,150$, 250 and $350 \mathrm{mM}$ ) on growth of two sugar beet varieties namely Madison and 7233- $P_{29}$. Plants were harvested after 8 weeks from sowing. He showed that all of growth characters were significantly decreased by increasing salinity levels. However, the sensitivity of the different characters to salinity varied. Total leaf area was reduced by $57.6 \%$ (average of the two varieties) in plants grown at high level of salinity $(350 \mathrm{mM})$ compared to the control (non- stressed plants). Leaf number per plant was significantly decreased as salinity increased in both varieties. However, low level of salt treatment $(50 \mathrm{mM})$ slightly increased leaf number per plant. This increase was not statistically significant. Cultivar Madison had greater reduction effect on leaf numbers due to salinity. The results showed that the leaves number was less affected than leaf area by salinity. It was suggested that most of the reduction in plant leaf area due to salinity was caused by the inhibition leaf expansion. Salt stress significantly reduced dry matter production. Total plant dry matter at the highest salinity (350 mM) was decreased by $50.6 \%$ (mean of both varieties) compared to control. Salinity stress caused decreases in shoots and roots dry weights for both varieties, but the reduction in roots dry weight was greater than shoots dry weight. A possible reason for dry matter reduction could be the greater reduction in uptake and utilization of mineral nutrients by plants under salt stress.

\section{Effect on seedling vigor}

Data presented in (Table 6) demonstrate the effect of three salt concentrations of seawater i.e. 2000, 4000 and 8000 ppm, sugar beet varieties and their interaction on seedling vigor after 30 days from sowing. The results indicated that increasing salinity levels from 2000 to 4000 ppm did not significantly affect the seedling vigor, on the other hand increasing salinity levels up to 8000 caused significant decreases for all studied varieties. The highest and the lowest values were generally recorded by the salt treatments of $2000 \mathrm{ppm}$ and 8000 ppm respectively. Results also showed that the variety Soultan recorded the highest mean value of seedling vigor (653) followed by Desprez (585), Maghribil (573), Clorvis (565), MK2134 (561) and Kawmira (552) while the varieties Helsiniki and LP16 recorded the lowest mean values (32.8 and 63.4 respectively). In respect to the interaction effect between salinity levels and sugar beet varieties on seedling vigor, results showed that the

Table 6. Seedling vigor of sugar beet varieties as affected by salinity levels (after 30 days from sowing)

\begin{tabular}{|c|c|c|c|c|}
\hline \multirow{2}{*}{ Varieties } & \multicolumn{3}{|c|}{ Salinity levels (ppm) } & \multirow{2}{*}{ Means } \\
\hline & 2000 & 4000 & 8000 & \\
\hline 1- Clorvis & $635 \mathrm{~b}$ & $574 \mathrm{~cd}$ & $486 \mathrm{f}$ & 565 B \\
\hline 2- Soultan & $693 a$ & $664 a b$ & $603 \mathrm{bc}$ & $653 \mathrm{~A}$ \\
\hline 3- Motabinco & $379 \mathrm{gh}$ & $366 \mathrm{~h}$ & $292 \mathrm{i}$ & $346 \mathrm{FG}$ \\
\hline 4- Ras poly & $484 \mathrm{f}$ & $479 \mathrm{fg}$ & $246 \mathrm{ij}$ & $403 \mathrm{E}$ \\
\hline 5- Kawemira & $617 \mathrm{bc}$ & $558 \mathrm{de}$ & $478 \mathrm{fg}$ & $552 \mathrm{BC}$ \\
\hline 6- Toro & $379 \mathrm{gh}$ & $361 \mathrm{~h}$ & $372 \mathrm{gh}$ & $371 \mathrm{EF}$ \\
\hline 7- Helsiniki & $98.4 \mathrm{klm}$ & $000 n$ & $000 n$ & $32.8 \mathrm{i}$ \\
\hline 8- FD 9902 & $378 \mathrm{gh}$ & $359 \mathrm{~h}$ & $242 \mathrm{ij}$ & $327 \mathrm{G}$ \\
\hline 9-Egypt06nn2 & $410 \mathrm{gh}$ & $385 \mathrm{gh}$ & $281 \mathrm{ij}$ & 359EFG \\
\hline 10-Dema poly & $372 \mathrm{gh}$ & $343 \mathrm{hi}$ & $270 \mathrm{ij}$ & $327 \mathrm{G}$ \\
\hline 11- Lp 16 & $138 \mathrm{k}$ & $34.9 \mathrm{~m}$ & $17.2 \mathrm{~m}$ & $63.4 \mathrm{i}$ \\
\hline 12- FD 9901 & 314 hi & $252 \mathrm{ij}$ & $209 j$ & $259 \mathrm{H}$ \\
\hline 13- Tenor & $442 \mathrm{fg}$ & 335 hi & $323 \mathrm{hi}$ & $367 \mathrm{EF}$ \\
\hline 14- LP 13 & $585 \mathrm{~cd}$ & $621 \mathrm{bc}$ & $250 \mathrm{ij}$ & $486 \mathrm{CD}$ \\
\hline 15- Baraka & $397 \mathrm{gh}$ & $330 \mathrm{hi}$ & $281 \mathrm{ij}$ & $336 \mathrm{G}$ \\
\hline 16- MK 2134 & $639 \mathrm{~b}$ & 571 cde & $472 \mathrm{fg}$ & $561 \mathrm{~B}$ \\
\hline 17- Samba & $442 \mathrm{fg}$ & $467 \mathrm{fg}$ & $354 \mathrm{~h}$ & $422 \mathrm{DE}$ \\
\hline 18- Henol & 525 ef & $488 f$ & $484 f$ & $500 \mathrm{C}$ \\
\hline 19-Egypt 06nn1 & 521 ef & $476 \mathrm{fg}$ & $350 \mathrm{hi}$ & 449CDE \\
\hline 20- MK 2135 & 501 ef & 502 ef & $323 \mathrm{hi}$ & $442 \mathrm{DE}$ \\
\hline 21- Maghribel & $603 \mathrm{bc}$ & $599 \mathrm{bcd}$ & 517 ef & $573 \mathrm{~B}$ \\
\hline 22- Desprez & $658 a b$ & $630 \mathrm{~b}$ & $465 \mathrm{fg}$ & 585 B \\
\hline Means & $465 \mathrm{~A}$ & $426 \mathrm{~A}$ & $333 \mathrm{~B}$ & \\
\hline
\end{tabular}


response of the investigated sugar beet varieties differed greatly according to salinity levels. This significant effect of the above interaction means that the varieties did not respond similarly to the salinity levels. Results also showed that the highest values of seedling vigor were recorded by the variety Soultan with 2000 ppm and 4000 ppm (693 and 664 respectively).

\section{Salt tolerance index}

The data presented in (Tables 2-6) revealed clearly the wide variations on germination $\%$ and the most important seedling growth traits among the 22 investigated sugar beet varieties to salinity levels, particularly at the highest level of seawater concentrations, i.e 8000 ppm. Variations among the tested varieties in germination \% ranged from 0.0 to $90 \%$ and in seedling vigor from 17.2 or less to 603 at the salinity level of $8000 \mathrm{ppm}$. To create a reasonable classification of these tested 22 varieties to their response or their salt tolerance, the data in Tables (2-6) should be recalculated and arranged in descending order as shown in Table (7).

It is worth to mention here to the well know fact that good germination means good plant stand,

good seedling vigor and consequently good yield. So the following suggested classification is mainly based on germination \% and seedling vigor of the investigated varieties

Depending on the data presented in Table (7) the twenty two investigated varieties could be classified into five groups or categories according to their relative salt tolerance as shown in Table (8) and Figure (1).

Table 7. Germination and seedling growth traits of sugar beet varieties as affected by salinity stress (8000 ppm) (after 30 days from sowing)

\begin{tabular}{|lccccc|}
\hline Varieties & \multicolumn{6}{c|}{ Germination and seedling growth traits } \\
\cline { 2 - 6 } & $\begin{array}{c}\text { G.P. } \\
\text { (\%) }\end{array}$ & G.R. & $\begin{array}{c}\text { S.W. } \\
(\mathbf{m g})\end{array}$ & $\begin{array}{c}\text { S.L. } \\
(\mathbf{c m})\end{array}$ & S.V. \\
\hline Soultan & $90 \mathrm{a}$ & $0.68 \mathrm{~d}$ & $50.9 \mathrm{a}$ & $6.7 \mathrm{a}$ & $603 \mathrm{a}$ \\
Kawmira & $90 \mathrm{a}$ & $0.7 \mathrm{ab}$ & $48.8 \mathrm{ab}$ & $5.3 \mathrm{~cd}$ & $478 \mathrm{~b}$ \\
Desprez & $86 \mathrm{a}$ & $0.74 \mathrm{bc}$ & $41.2 \mathrm{bc}$ & $5.4 \mathrm{~cd}$ & $465 \mathrm{~b}$ \\
MK2134 & $80 \mathrm{~b}$ & $0.70 \mathrm{~cd}$ & $50.0 \mathrm{a}$ & $5 . \mathrm{bc}$ & $472 \mathrm{~b}$ \\
Henol & $78 \mathrm{~b}$ & $0.73 \mathrm{bc}$ & $42.4 \mathrm{bc}$ & $6.2 \mathrm{~b}$ & $484 \mathrm{~b}$ \\
Maghribel & $76 \mathrm{~b}$ & $0.74 \mathrm{bc}$ & $48.5 \mathrm{ab}$ & $6.8 \mathrm{a}$ & $517 \mathrm{~b}$ \\
Clorvis & $74 \mathrm{~b}$ & $0.72 \mathrm{c}$ & $49.2 \mathrm{a}$ & $6.6 \mathrm{a}$ & $486 \mathrm{~b}$ \\
Samba & $68 \mathrm{c}$ & $0.74 \mathrm{bc}$ & $45.3 \mathrm{~b}$ & $5.2 \mathrm{~cd}$ & $354 \mathrm{c}$ \\
Egypt 06nn1 & $66 \mathrm{c}$ & $0.73 \mathrm{bc}$ & $39.3 \mathrm{~cd}$ & $5.3 \mathrm{~cd}$ & $350 \mathrm{c}$ \\
\hline
\end{tabular}

\begin{tabular}{|lccccc|}
\hline Toro & $64 \mathrm{c}$ & $0.77 \mathrm{a}$ & $36.6 \mathrm{de}$ & $5.8 \mathrm{bc}$ & $372 \mathrm{c}$ \\
Tenor & $62 \mathrm{~cd}$ & $0.76 \mathrm{ab}$ & $39.4 \mathrm{~cd}$ & $5.2 \mathrm{~cd}$ & $323 \mathrm{c}$ \\
MK2135 & $62 \mathrm{~cd}$ & $0.75 \mathrm{abc}$ & $40.4 \mathrm{c}$ & $5.2 \mathrm{~cd}$ & $323 \mathrm{c}$ \\
LP13 & $58 \mathrm{de}$ & $0.74 \mathrm{bc}$ & $39.0 \mathrm{cde}$ & $4.3 \mathrm{e}$ & $250 \mathrm{de}$ \\
Motabinco & $54 \mathrm{de}$ & $0.73 \mathrm{bc}$ & $39.3 \mathrm{~cd}$ & $5.4 \mathrm{~cd}$ & $292 \mathrm{~d}$ \\
Egypt 06nn2 & $54 \mathrm{de}$ & $0.74 \mathrm{bc}$ & $36.0 \mathrm{de}$ & $5.2 \mathrm{~cd}$ & $281 \mathrm{~d}$ \\
Baraka & $52 \mathrm{e}$ & $0.74 \mathrm{bc}$ & $36.6 \mathrm{de}$ & $5.4 \mathrm{~cd}$ & $281 \mathrm{~d}$ \\
Ras poly & $50 \mathrm{e}$ & $0.70 \mathrm{~cd}$ & $33.3 \mathrm{e}$ & $4.9 \mathrm{~d}$ & $246 \mathrm{de}$ \\
Dema poly & $50 \mathrm{e}$ & $0.76 \mathrm{ab}$ & $36.6 \mathrm{de}$ & $5.4 \mathrm{~cd}$ & $270 \mathrm{de}$ \\
FD9902 & $44 \mathrm{f}$ & $0.72 \mathrm{c}$ & $34.0 \mathrm{de}$ & $5.5 \mathrm{~cd}$ & $242 \mathrm{de}$ \\
FD9901 & $36 \mathrm{~g}$ & $0.73 \mathrm{bc}$ & $29.0 \mathrm{f}$ & $5 . \mathrm{bc}$ & $209 \mathrm{e}$ \\
LP16 & $10 \mathrm{~h}$ & $0.56 \mathrm{e}$ & $7.23 \mathrm{~g}$ & $1.7 \mathrm{f}$ & $17.2 \mathrm{f}$ \\
Helsiniki & $00 \mathrm{i}$ & $0.00 \mathrm{f}$ & $00.0 \mathrm{~h}$ & $0.0 \mathrm{~g}$ & $000 \mathrm{~g}$ \\
\hline
\end{tabular}

G.P.=germination percentage (\%).

G.R. = germination rate.

S.L.seedling length $(\mathrm{cm})$.

S.V. = seedling vigor

S.W. = seedling fresh weight $(\mathrm{mg})$.

Table 8. The rating of the twenty two tested varieties to their salt tolerance at salinity stress of $(8000$ ppm) on germination \% results

\begin{tabular}{|ccccc|}
\hline $\begin{array}{c}\text { Highly } \\
\text { sensitive } \\
\text { varieties }\end{array}$ & $\begin{array}{c}\text { Sensitive } \\
\text { varieties }\end{array}$ & $\begin{array}{c}\text { Moderately } \\
\text { tolerant } \\
\text { varieties }\end{array}$ & $\begin{array}{c}\text { Tolerant } \\
\text { varieties }\end{array}$ & $\begin{array}{c}\text { Highly } \\
\text { tolerant } \\
\text { varieties }\end{array}$ \\
\hline Helsiniki & Egypt & Egypt & Desprez & Soultan \\
& 06nn2 & $06 n n 1$ & & \\
LP16 & Motabinco & MK2135 & Mk2134 & Kawmira \\
& Baraka & Samba & Maghribel & \\
& Dema poly & Ras poly & Clorvis & \\
& FD9901 & Toro & LP13 & \\
& FD9902 & Tenor & Henol & \\
\hline
\end{tabular}

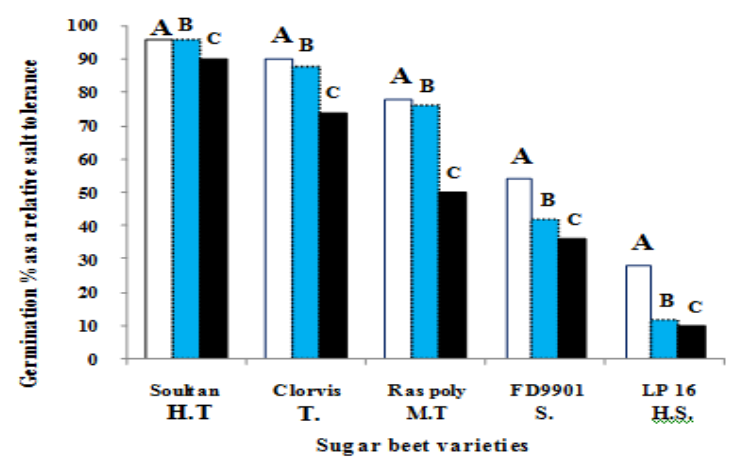

Fig. 1. Growth response of some sugar beet varieties to salinity stress

H.T.: Highly salt tolerant, germination \% higher than $85 \%$ T.: Salt tolerant, germination $\%$ not less than $70 \%$.

M.T.: Moderately salt tolerant, germination $\%$ not less than $60 \%$.

S.: Sensitive salt tolerant, germination $\%$ not less than $50 \%$.

H.S.: Highly sensitive salt tolerant, germination \% not less than $50 \%$ 


\section{REFERENCES}

Dadkhah, A.R. 2011. The effect of salinity on growth and leaf photosynthesis of two sugar beet (Beta vulgaris, L.) cultivars. J. Agric. Sci. Technol., 13: 1001-1012.

Ghoulam, C., Foursy, A. and Fares, K. 2002. Effects of salt stress on growth, inorganic ions and proline accumulation in relation to osmotic adjustment in five sugar beet cultivars. Environ. and Exper. Bot. 47: 39-50.

Heuer, B. and Plaut, Z. 1989. Photosynthesis and osmotic adjustment of two sugar beet cultivars grown under saline conditions. J. Exp. Bot. 40(213): 437-440.

Jafarzadeh, A.A. and Allasgharzad, N. 2007. Salinity and salt composition effects on seed germination and root length of four sugar beet cultivars. International cientific Conference, Polananad Detvou, Slovakia, September 2007: 17- 20.

Jamil, M., Rehman, S. and Rha, E.S. 2007. Salinity effect on plant growth, PSII photochemistry and chlorophyll content in sugar beet (Beta vulgaris, L.) and cabbage (Brassica oleracea capitata, L.) Pak. J. Bot., 39(3): 753-760.

Kaffka, S. and Kurt, H. 2004. The effects of saline soil, irrigation, and seed treatments on Sugar beet. J. Sugar Beet Res., 41(3):61-72.

Rizk, T.Y., Edris, A.A. and Zizy, M. Abbas 2002. Effect of salinity on germination, growth and accumulative forage yield of some recently developed clover varieties. Int. Symp. On Optimum Resources Utilization in Salt-Affected Ecosystems in Arid and Semi Arid Regions, Cairo 8-11 Apr., 616-625.

Rizk, T.Y., Al-Hasan, A.M. and El-Tekriti, R.A. 1981. Effect of temperatures and salinity levels on germination and early growth of two local annual medics. Mesopotamia J. Agric., 16(1): 67-92.

SAS. 1995. Statistical Analysis System. $6^{\text {th }}$ Ed., Institute Inc., Gary., NC., USA.

Turhan, H. and Ayaz, C. 2004. Effect of salinity on seedling emer-gence and growth of sunflower (Helianthus annuus L.) cultivars. Int. J. Agric. Biol. 6(1): 149-152. 